\title{
The Bertrand Russell Society (USA)
}

From responses to the original letters to potential members, a foundling group was set up from among those who had a strong motivation to actively participate in organizing the Russell Society.

The group is comprised of the following members:

Cranford, Dr. Peter G.

$21081 / 2$ Wa1ton Way

AUGUSTA, GA 30904

Home: $\quad 404-736-9656$

$404-736-2331$

Office: $404-736-3514$

404-736-6384

Davis, Mr. Robert

1737 Silverwood Terrace

LOS ANGELES, CA 90026

213-665-3983

Eisler, Mr. Lee

Rd 1

COOPERSBURG, PA 18036

215-346-7687

Garstens, Dr. M.A.

913 Buckingham $\mathrm{Dr}$

SILVER SPRING, MD 20901

Home: 301-434-0652

Office: $202-692-4219$

John, Mr. Hurst

2205 Country Club Dr.

COLUMBIA, MO 65201

office: $314-442-1101$

Moore, Mr. M.C.

Augusta College

AUGUSTA, GA 30904

Nathan, Dr. Otto

state of Albert Einstein

NEW YORK, NY 10011

212-477-2948

$212-473-6400$

Neilands, Prof. J.B.

Biochemistry Department

Biochenistry Department

Bniversity of Californi

415-642-6000

Pitt, Prof. Jack

1135 E. Santa Anna

FRESNO, CA 93704

Home: $\quad 209-226-4187$

Office: $209-487-2621$

Roberts, Prof. Don D.

niversity of Waterloo

WATERLOO, ON

Home: $\quad 519-885-0315$

Office: $519-885-1211$ Ext 26383

Slezak, Mr. Gary, M.

1768 W. 95th P1.

CHICAGO, IL 60643

Tait, Mrs. Katharine

FALLS VILLAGE, CT 0605

Home: 203-824-0035

Home: $\quad 404-736-4986$

Office: 404-736-2234 Ext 328

Since the last report, work has consisted of sifting from many suggestions what the aims of the society should be. 
It was judged best that we decide upon an over-all purpose. Though this seemed to be a simple problem, it was necessary to proceed with

care so as not to intimate that there would develop a "cult of personality" with its invidious connotation. On the other hand, the overwhelming

All correspondence was reviewed to see if those outside of the organizing group were in general agreement.

Mrs. Katharine Tait had written, "Promote his purposes for the world". In one form or other this was expressed by a large majority of committee members and others, and has been accepted - subject to possible modification.

For a time we shall be concerned in working out by mail a more explicit set of aims under the over-all purpose. There was a strong interest in promoting peace, happiness, and providing ethical and moral leadership. When the preliminary thinking has been completed, the group will meet in New York for the formal founding of the society. This will be followed by a proposed meeting open to charter members.

In the meantime we earnestly solicit comments from readers of fiusse 2l. They can be addressed to any member of the above committee.

Augusta, Georgia

Peter G. Cranford 